\title{
Culturable endophytic fungal diversity in cassava tubers of Indonesia
}

\author{
ANASTASIA TATIK HARTANTI ${ }^{1}$, FELICIA NIKE SUSANTI ${ }^{1}$, VIVITRI DEWI PRASASTY ${ }^{1}$, \\ NANI RADIASTUTI ${ }^{2, \bullet}$ \\ ${ }^{1}$ Faculty of Biotechnology, Universitas Katolik Atma Jaya Indonesia. Jl. Jenderal Sudirman 51, Jakarta Pusat 12930, Jakarta, Indonesia \\ ${ }^{2}$ Department of Biology, Faculty of Science and Technology, UIN Syarif Hidayatullah. Jl. Ir. H. Djuanda No. 95 Ciputat, South Tangerang 15412, \\ Banten, Indonesia. Tel.: +62-21-7401925, Fax.: +62-21-7493315, `email: nani.radiastuti@uinjkt.ac.id
}

Manuscript received: 30 December 2020. Revision accepted: 7 February 2021.

\begin{abstract}
Hartanti AT, Susanti FN, Prasasty VD, Radiastuti N. 2021. Culturable endophytic fungal diversity in cassava tubers of Indonesia. Biodiversitas 22: 1250-1260. Fungal endophytes are found in plant tissue and do not harm the host plant. Cassava (Manihot esculenta Crantz) is the third staple food besides rice and corn. This study aimed to identify the diversity of endophytic fungi in the cassava from several regions in Indonesia, including Bogor, Lembang, Makasar, Serang, Singaraja (Buleleng), Subang, Wonogiri, and Wonosobo. The endophytic fungi were isolated and were molecularly characterized using the internal transcribed spacer (ITS) rDNA sequence (ITS4 and ITS5). Phylogenetic analysis was performed by using the MEGA 7 with a bootstrap value of 1000 repetitions. All 14 isolates of endophytic fungi were isolated from different regions. Of these six isolates belonged to genus Fusarium (F. solani FS5, F. lichenicola FS2, F. lichenicola FS4, F oxysporum FS1, F. falciforme FS3, F. falciforme FS6), and four to the genus Aspergillus (Aspergillus sp. FS7, Aspergillus sp. FS8, Aspergillus sp. FS9 and A. fumigatus FS10). In addition, Nectria pseudotrichia, Lasiodiplodia sp., Penicillium citrinum, and Schizophyllum commune were also isolated from cassava tubers. In conclusion, it suggested that diverse endophytic fungi colonize tubers of cassava growing in Indonesia.
\end{abstract}

Keywords: Cassava, diversity, endophytic fungi, ITS rDNA sequence

\section{INTRODUCTION}

Endophytic fungi inhabit plant tissue and do not cause disease symptoms in their host plants. These fungi are present in tissues of seeds, flowers, fruits, stems, roots, and tubers, and protect host plants from various environmental stresses. A symbiotic mutualism relationship occurs between endophytic fungi and their associated host plants (Chadha et al. 2014). Indonesia is one of the largest developing country producing cassava tubers. This tuber has great starch content, low price, and easy to grow even in low fertile soils. Cassava is expected to substitute starch source from rice with a very high crop failure rate due to a large number of pests, diseases, and climate changes that can cause drought (Sucipto et al. 2015). However, the community of endophytic fungi inhabiting cassava tubers is not well studied in Indonesia.

One endophyte Guignardia endophyllicola was isolated from cassava stalks originating from agricultural land and supporting forest in Parakan Salak Village, Sukabumi (Suciatmih and Supriyati 2016). On the other hand, endophytic fungi belonging to Penicillium, Fusarium, and Aspergillus were isolated from cassava growing in the Nature Reserve Mount, East Nusa Tenggara (Ilyas 2006).

In this study, we focused on the isolation and molecular identification of endophytic fungi isolated from cassava tubers collected from Bogor, Lembang, Makasar, Serang, Singaraja (Buleleng), Subang, Wonogiri, and Wonosobo of Indonesia. Moreover, information on the diversity of endophytic fungi associated with cassava tubers is cultivated in Indonesia and it is still lacking especially the molecular identification of the endophytic fungi.

In general, identification of endophytic fungi has been mostly carried out by morphological observations. However, it has challenges to identify at the species level. At first, endophytic fungi may be Mycelia sterilia (Lacap et al. 2003; Hidayat et al. 2016), where reproductive structures are not formed for morphological characterization. Therefore, in this study, we report the diversity of endophytic fungi in cassava tubers originating from several regions in Indonesia by identifying genetic differences using sequences of ITS rDNA with ITS4 and ITS5 primers to complement morphological characters.

\section{MATERIALS AND METHODS}

\section{Materials}

Cassava (Manihot esculenta) samples were collected from October 13, 2016 to December 19, 2017 in traditional markets in Bogor 106 $43^{\prime} 30^{\prime \prime}-106^{\circ} 51^{\prime} 00^{\prime \prime}$ Longitude East (LE) and 30'30" - 6 $6^{\circ} 41^{\prime} 00^{\prime \prime}$ Latitude South (LS); Serang $105^{\circ} 7^{\prime}-105^{\circ} 22^{\prime}$ LE and $5^{\circ} 50^{\prime}-6^{\circ} 21^{\prime}$ LS; Singaraja $08^{\circ}$ $03^{\prime} 40^{\prime \prime}-08^{\circ} 23^{\prime} 00^{\prime}$ " LS and $114^{\circ} 25^{\prime} 55^{\prime \prime}-115^{\circ} 27^{\prime}$ ' 28' LE; Subang 6 34 '15.96" LS and $-107^{\circ} 45^{\prime} 76^{\prime \prime}$ LE; Wonogiri $7^{\circ} 32^{\prime}-8^{\circ} 15^{\prime}$ LS and $110^{\circ} 41^{\prime}-111^{\circ} 18^{\prime}$ LE; Wonosobo $7^{\circ} 8^{\prime} 8^{\prime \prime}$ LS and $109^{\circ} 55^{\prime} 48^{\prime \prime}$ LE.

\section{Endophytic fungi isolation}

Fresh cassava tuber samples were peeled and washed under running water for $10 \mathrm{~min}$. The tubers were cut into 2 $\times 2 \mathrm{~cm}$. The tuber pieces were then sterilized with $70 \%$ 
alcohol for $1 \mathrm{~min}$ and followed by $1 \%$ sodium hypochlorite solution for $2 \mathrm{~min}$. The tuber samples were soaked and shaken with sterile distilled water three times for each 5 min. The sterilized samples were dried with sterile tissue paper for $3 \mathrm{~h}$. The surface of the cassava samples was sliced off and the inside part of cassava tubers was taken aseptically and placed on a petri dish containing potato dextrose agar (PDA) medium and chloramphenicol. Each petri dish contained three pieces of $1.5 \times 1.5 \mathrm{~cm}$ cassava tubers from one sampling location. The success of surface sterilization was carried out using $10 \mu \mathrm{L}$ of the last rinse distilled water of the cassava tuber, washed, and smeared on a sterile PDA medium using a micropipette. The test was carried out to find out if there were contamination on the surface-sterilized cassava tubers. The cultures were incubated at $28^{\circ} \mathrm{C}$ for 2 weeks. The fungal growth was monitored daily.

\section{DNA isolation}

For DNA isolation, the fungus was cultured on PDA slants for four days at $30^{\circ} \mathrm{C}$. The fungal mycelium was transferred into a $1500 \mu \mathrm{L}$ Eppendorf tube containing 500 $\mu \mathrm{L}$ nuclease free water (NFW). Centrifugation was carried out at 9,600 $\times \mathrm{g}$ for $10 \mathrm{~min}$. The supernatant was discarded and pellet was crushed by using a sterile pestle until the entire mycelium was smooth. DNA isolation was performed using the DNA protocol Phytopure ${ }^{\mathrm{TM}}$ kit extraction (GE Healthcare, UK) with modifications. Reagent 1 was added as much as $300 \mu \mathrm{L}$ into the pellet and resuspended with a micropipette for cell lysis. RNAse (20 $\mu \mathrm{M})$ was added as much as $3 \mu \mathrm{L}$, resuspended and incubated at $37^{\circ} \mathrm{C}$ for $30 \mathrm{~min}$. A total of $200 \mu \mathrm{L}$ of reagent 2 was added and shaken until blended. The samples were incubated at $25^{\circ} \mathrm{C}$ for $10 \mathrm{~min}$ and the ice temperature for 20 min. The mycelium suspension was added with $500 \mu \mathrm{L}$ of cold solvent (phenol:chloroform: isopropanol $=1: 1: 1$ ), then shaken for $10 \mathrm{~min}$ at $25^{\circ} \mathrm{C}$. It was centrifuged at a speed of $9,600 \times \mathrm{g}$ at $4^{\circ} \mathrm{C}$ for $10 \mathrm{~min}$. The supernatant was transferred into a $1500 \mu \mathrm{L}$ of new Eppendorf tube. Cold isopropanol was added as much as half volume of the supernatant, and stirred slowly until homogenous. It was centrifuged at $16,200 \times \mathrm{g}$ at $4^{\circ} \mathrm{C}$ for $10 \mathrm{~min}$. The supernatant was removed. A total of $50 \mu \mathrm{L}$ of $70 \%$ cold ethanol was added and centrifuged at $16,200 \times \mathrm{g}$ at $4{ }^{\circ} \mathrm{C}$ for $10 \mathrm{~min}$. The supernatant was discarded. The pellets were dried in oven at $37^{\circ} \mathrm{C}$ for $30 \mathrm{~min}$. NFW was added as much as $100 \mu \mathrm{L}$ and store at $-20^{\circ} \mathrm{C}$ (Mostert et al. 2001).

\section{Molecular identification of endophytic fungi}

The hyphae of the fungal isolate maintained in a petri dish were taken inoculated in the potato dextrose agar (PDA) and incubated for 5 days at $25^{\circ} \mathrm{C}$. DNA isolation was performed using the DNA protocol Phytopure ${ }^{\mathrm{TM}}$ kit extraction (GE Healthcare, UK) with modifications.

PCR amplification of ITS rDNA sites was carried out with ITS 5 (forward: 5'-TCCTCCGCTTATTGATATGC$3^{\prime}$ ) and ITS 4 (reverse: 5'-TCCGTAGGTGAACCTGCGC3') primers (White et al. 1990) by using Gene Amp ${ }^{\circledR}$ PCR System 2400. The PCR reaction for each sample was carried out in $50 \mu \mathrm{L}$ of the reaction mixture that contained
$2 \mu \mathrm{L}$ of DNA genome with a concentration of approximately $100 \mathrm{ng} / \mu \mathrm{L}$. Each primer (ITS4 and ITS5) was added at $1.25 \mu \mathrm{L}$ with a concentration of $10 \mu \mathrm{M}$ (Innis et al. 2012), in amount of $25 \mu \mathrm{L}$ of Go Taq Green Master Mix PCR 2x, and $20.5 \mu \mathrm{L}$ of NFW. The PCR condition that was used as follows: pre-denaturation was at $94^{\circ} \mathrm{C}$ for $2 \mathrm{~min}$, followed by 35 cycles at $94^{\circ} \mathrm{C}$ for $15 \mathrm{sec}$ in denaturation process, annealing was at $55^{\circ} \mathrm{C}$ for $30 \mathrm{~min}$, elongation was at $72^{\circ} \mathrm{C}$ for $1 \mathrm{~min}$, and final elongation was at $72^{\circ} \mathrm{C}$ for $5 \mathrm{~min}$. The PCR results were visualized with agarose gel $1 \% 60$ volts for $90 \mathrm{~min}$, then it was immersed in a solution of ethidium bromide for $15 \mathrm{~min}$, and it was rinsed with distilled water. The observation was carried out under UV light.

Molecular analysis was performed at the First Base Company in Malaysia. The results of the DNA sequence were edited by using ChromasPro and nucleotide base results blasted by using the basic local alignment search tool nucleotides (BLASTN) platform. After the blast results were obtained, the out-group and reference data can be downloaded from GenBank (www.ncbi.nih.gov/Genbank). All data were aligned by using the molecular evolution and genetic analysis 7 (MEGA 7) platform. The phylogenetic tree was constructed by using the Maximum Likelihood (ML) Tamura-Nei model or Neighbor-Joining (NJ) by using MEGA 7.

\section{Morphological identification of endophytic fungi}

Morphological identification was carried out by macroscopic and microscopic morphological observations (Barnett and Hunter 1998). Macroscopic observations were carried out by observing the fungal diameter size, colony color on PDA media, colony surface structure, and colony edges. Microscopic observations were carried out by observing the reproductive structure using Riddell's classic slide culture method (Riddell 1950).

\section{RESULTS AND DISCUSSION}

A total of 14 isolates of endophytic fungi from cassava tubers were isolated and identified based on molecular characterization. These endophytes were found in cassava tubers from eight regions of Indonesia. Based on molecular characterization the endophytic fungi were from genus Aspergillus (4 isolates), Fusarium (6 isolates), and other four isolates included Lasiodiplodia sp., Nectria pseudotrichia, Penicillium citrinum, and Schizophyllum commune (Table 1).

Previous study reported that endophytic fungi were isolated from other parts of cassava such as petiole (Suciatmih and Supriyati 2016) and root (Ilyas 2006). This study provided important information regarding the diversity of endophytic fungi that was found in fresh cassava tubers. Endophytic fungi also can be found in other plants besides cassava, such as quina (Hidayat et al. 2016a), maize (Suriani and Muis 2017), and mangosteen (Akmalasari et al. 2013). The phylogenetic construction tree of Fusarium spp. was used as reference sequence retrieved GenBank. 


\section{Aspergillus spp.}

A total of four isolates of Aspergillus were successfully isolated from cassava tubers, originating from areas of Bogor (FS7), Wonogiri (FS8), Serang (FS9), and Singaraja (FS10). Based on molecular analysis of phylogenetic trees, it identified as three strains of Aspergillus sp. (FS7, FS8, and FS9 strains) and one A. fumigatus strain (FS10 strain). Diaporthe angelicae CBS 123215 was used as out-group. Based on the ITS rDNA sequence analysis, the FS7, FS8, and FS9 strains belonged to the same clade as A. flavus 26, 10, 14, 24, C1931, MB42, and 12.25. Meanwhile, A. oryzae FS1 125, and $A$. parasiticus DAOM 225948 with a bootstrap value was $97 \%$, led the species name cannot be determined. FS10 strain was A. fumigatus with a bootstrap value is $100 \%$ based on phylogenetic tree analysis. Based on the phylogenetic analysis, there were three species of fungi in the same clade with the FS7, FS8 and FS9 strains, they were $A$. flavus, $A$, oryzae, and $A$. parasiticus. These isolates belonged to the genus Aspergillus. Based on ITS rDNA sequences analysis, strain FS7, FS8, and FS9 identified at genus level (Figure 1.A).

Colony of Aspergillus sp. FS7, FS8, and FS9 spread over the PDA media with a $6 \mathrm{~cm}$ diameter after 4 days of incubation time. Macroscopic observation showed that the colony was green and had a velvety surface (Figure 1.B, 1.D, and 1.F). The FS7, FS8, and FS9 strains have good conidiophore, insulated hyphae, round vesicles, contained fialid conidiogenous cell and round conidia (Figure 1.C). The FS7, FS8 and FS9 isolates have green colony, round conidia, and smooth surfaces. Aspergillus. flavus and $A$. parasiticus have green colony characteristics, round shape conidia, and smooth surfaces (Oramahi et al. 2006). A. oryzae has yellowish-green colony, round conidia, smooth and a little rough surface. Based on macroscopic observations the FS7, FS8, and FS9 strains resembled $A$. flavus. The process of molecular identification by using other genes, such as elongation factor $\alpha$, needs to be carried out for analysis of fungi until the species level and separated into different clades.

The growth of $A$. fumigatus FS10 strain spread unevenly on PDA media, $6 \mathrm{~cm}$ in diameter after 4 days of incubation. Colony surface was dark green powder. Microscopically, A. fumigatus has insulted hyphae, conidiophores that were upright, not contain septa, unbranched, and conidiophore's tip swelled to form vesicles. Fialid was vesicles bottle-shaped formed directly over vesicula that produced the round conidia (Figure 1.E and 1.G). Aspergillus fumigatus was fungi that harm humans. These fungal spores can cause respiratory diseases in humans, such as asthma, cystic fibrosis, and aspergillosis (Dagenais and Keller 2009). However, further research is needed to determine the positive and negative impacts of the strains derived from cassava tubers.

\section{Fusarium spp.}

Six strains of Fusarium spp. were isolated successfully from cassava tubers from areas of Wonosobo (FS1 and FS3), Wonogiri (FS2 and FS4), and Singaraja (FS6 and FS10). Molecular identification showed that isolates FS1FS6 were Fusarium oxysporum (FS1), F. lichenicola (FS2 and FS4), F. falciforme (FS3 and FS6), and F. solani (FS5) as depicted in Figure 2.

The FS1 strain formed monophyletic clade with $F$. oxysporum CBSI $133023 \mathrm{~T}$ and $F$. oxysporum YNMG-1 with a bootstrap value was 64\% (Figure 2.A); thus, strain FS1 was identified as $F$. oxysporum. The fungal colonies of $F$. oxysporum grew to fill a $6 \mathrm{~cm}$ diameter petri dish for 2 days of incubation in PDA media. The FS1 strain has a thick white mycelium like cotton. After 2 days, the colony turned purplish (Figure 2.B). The microscopic morphology observation of $F$. oxysporum, showed this fungus has much microconidium, oval shape, without insulation and hyalin. Macroconidia were not found, but had monophyalid conidiophore (Figure 2.C).

The FS2 and FS4 strains formed the same clade as $F$. lichenicola NRRL32434 with high bootstrap values (98\%). Thus, the FS2 and FS4 strains were identified as $F$. lichenicola species. The FS2 strain grew of $3 \mathrm{~cm}$ in $6 \mathrm{~cm}$ diameter size PDA media for 4 days with white mycelium growth on the edge of the colony (Figure 2.D). The FS4 strain grew up to $4 \mathrm{~cm}$ diameter on a $6 \mathrm{~cm}$-sized PDA media petri dish with 4 days of incubation time. The mycelium was white and thick like cotton. Based on macroscopic observation, the FS2 and FS4 strains changed PDA media color became somewhat reddish. Microscopic observation showed that microconidia have oval shape and hyalin without bulkhead (Figure 2.E). During the observation, macroconidia were not found in FS2 and FS4 strains.

Table 1. Endophytic fungi species found in cassava tubers from different regions of Indonesia

\begin{tabular}{|c|c|c|c|}
\hline $\begin{array}{c}\begin{array}{c}\text { Place of } \\
\text { origin }\end{array} \\
\end{array}$ & Date of isolation & $\begin{array}{c}\text { Isolate } \\
\text { code }\end{array}$ & Species \\
\hline Bogor & October 16, 2016 & FS7 & Aspergillus sp. \\
\hline Wonogiri & January 23, 2017 & FS8 & Aspergillus sp. \\
\hline Serang & November 7, 2016 & FS9 & Aspergillus sp. \\
\hline $\begin{array}{l}\text { Singaraja } \\
\text { (Buleleng) }\end{array}$ & February 17, 2017 & FS10 & A. fumigatus \\
\hline Wonosobo & January 16, 2017 & FS3 & Fusarium falciforme \\
\hline $\begin{array}{l}\text { Singaraja } \\
\text { (Buleleng) }\end{array}$ & February 17, 2017 & FS10 & $F$. falciforme \\
\hline Wonogiri & January 23, 2017 & FS2 & F. lichenicola \\
\hline Wonogiri & January 23, 2017 & FS4 & F. lichenicola \\
\hline Wonosobo & January 16, 2017 & FS1 & F. oxysporum \\
\hline Lembang & November 7, 2016 & FS5 & F. solani \\
\hline Makassar & December 19, 2017 & FS12 & Lasiodiplodia sp. \\
\hline Subang & November 7, 2016 & FS11 & Nectria pseudotrichia \\
\hline Subang & November 7, 2016 & FS13 & Penicillium citrinum \\
\hline Bogor & October 16, 2016 & FS14 & Schizophyllum commune \\
\hline
\end{tabular}




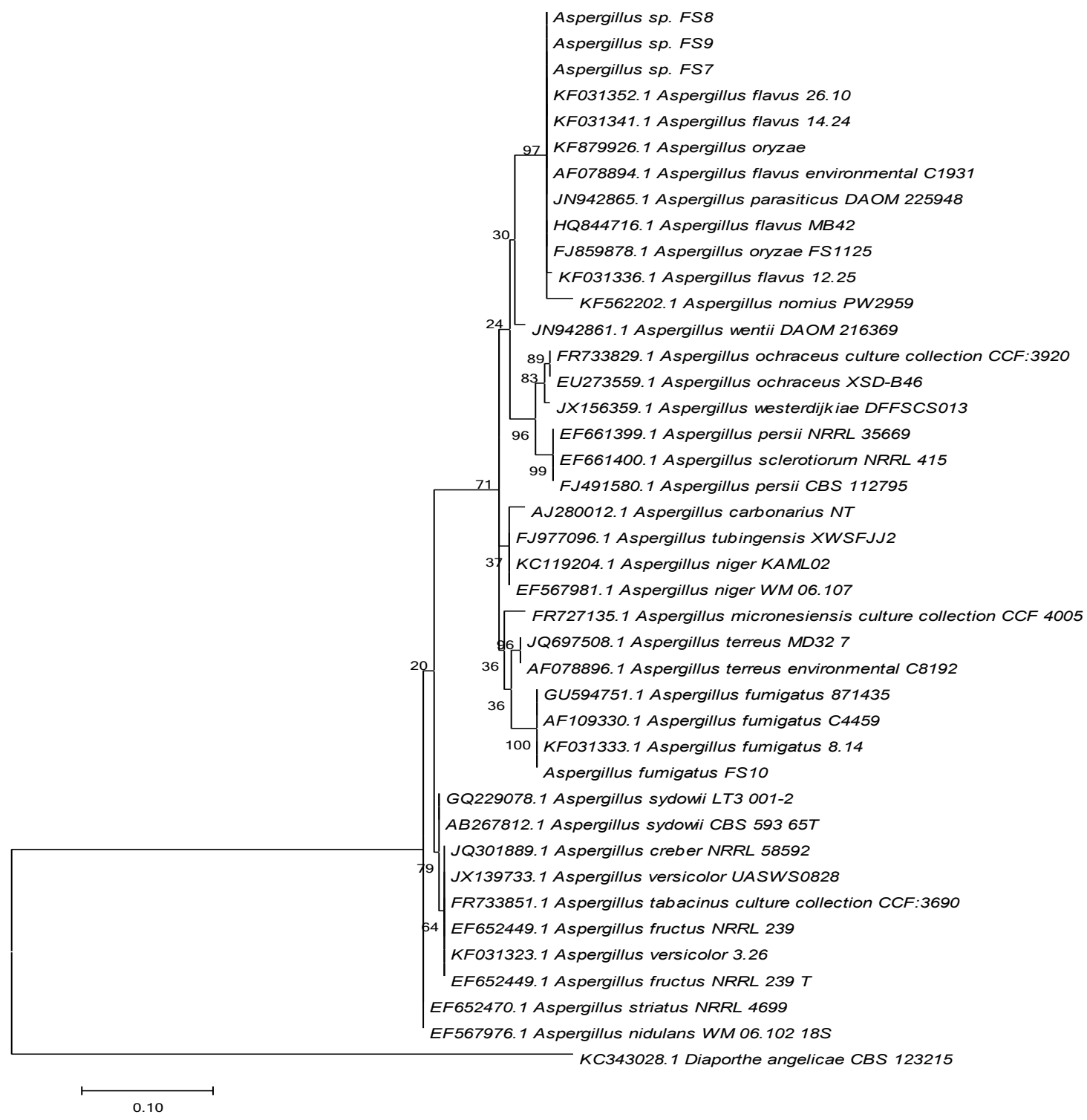

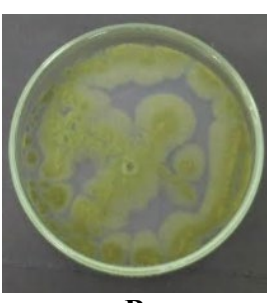

B

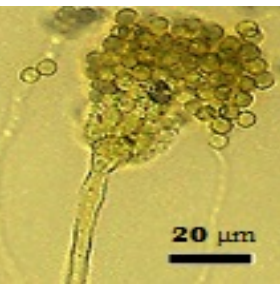

C

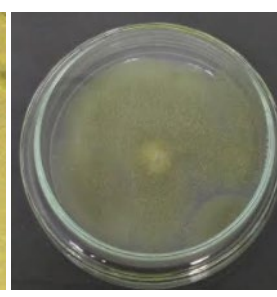

D

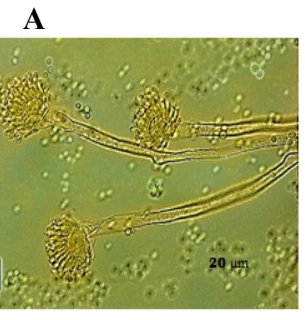

E

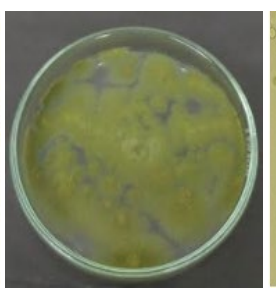

F

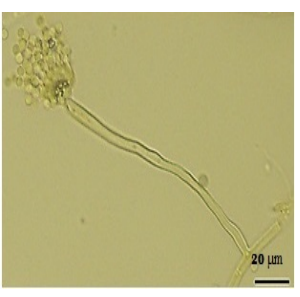

G

Figure 1. The phylogenetic tree of Aspergillus spp. based on the maximum likelihood analysis with 1000 bootstrap replicates. A. Diaporthe angelicae CBS123215 was used as the out-group and morphological profiles of endophytic fungi: B. Macroscopic and C. Microscopic profiles of Aspergillus sp. FS7; D. Macroscopic and E Microscopic profiles of Aspergillus sp. FS8; F. Macroscopic and G. Microscopic profiles of Aspergillus sp. FS9

The FS3 and FS6 strains formed a monophyletic clade with $F$. falciforme NRRL 32757 and the value of bootstrap was $88 \%$. Thus, it was identified as $F$. falciforme. In the FS3 strain, the colonies grew and covered the PDA media with a $6 \mathrm{~cm}$ diameter on the third day (Figure 2.F). Macroscopic observation revealed that this strain was white and cottony. The microconidia were oval, conidiophores without septa, and hyaline (Figure 2.G). Meanwhile, macroconidia were slightly curved with pointed ends, onebulkhead, and hyalin. The FS6 strain grew to cover the petri dish media with a $6 \mathrm{~cm}$ diameter on the third day. The colonies were white and thin than FS3 and had the same microscopic appearance as the FS3 strain.

The FS5 strain was identified as $F$. solani with a bootstrap value of $91 \%$ formed the same clade as $F$. solani NRRL 28579T (Figure 2.A), colonies on PDA media, grew 
up to $3 \mathrm{~cm}$ in diameter after two days of incubation (Figure $2 \mathrm{~h}$ ). Colonies were characterized by a slightly yellowishwhite color, thin-shape with cottony hyphae that were aerial and the colonies edge was irregular. Microconidia were oval without a bulkhead, and hyalin (Figure 2.I). Fusarium was also found in the other plants, such as maize (Suriani and Muis 2017), chili (Nurzannah et al. 2014), quina (Hidayat et al. 2016b), and Centella asiatica (Radiastuti et al. 2019). Fusarium generally produces a secondary metabolite, such as fumonisin. According to Onana et al. (2015), fumonisin has a negative impact on humans, which can stimulate cancer cell activity in humans. Fumonisin can be found in daily food products, such as cassava chips. Cassava chips that are stored for a long time (over 180 days) could increase fumonisin in cassava chips (Onana et al. 2015). This fungus plays a role as a biocontrol agent or pathogen resistance in several plants (Rubini et al. 2005).

In previous studies, $F$. oxysporum (FS1 strain) was able to increase resistance in tomato plants because it can kill pathogenic fungi, such as Phytophthora infestans, which causes tomato blight, and Cladosporium fulvum, which causes tomato leaf mold disease (Fuchs et al. 1997) and acts as a biocontrol agent in hydroponic plants (Thongkamngam and Jaenaksorn 2017). In banana plants, this fungus can kill pests and nematode worms that can damage crop yields (Waweru et al. 2014), whereas, in cassava plants, this fungus can cause dry rot disease (Boas et al. 2017). F. lichenicola (FS2 and FS4 strains) have similarities with Cylindrocarpon lichenicola. This fungus was isolated from cassava tubers from Wonogiri area. $F$. falciforme (FS3 and FS6 strains) has the similarity with Acremonium falciforme. This fungus was found from cassava tubers that collected from Wonosobo and Singaraja (Buleleng). F. falciforme is also found in palm plants as endophytic fungi (Song et al. 2016). F. lichenicola and $F$. falciforme are known as opportunistic pathogens. These fungi belong to tropical fungi that grow in high rainfall conditions (Irawati et al. 2014). These fungi are pathogens to humans and can cause several diseases, such as infection of the eye and keratinocytes' cornea because they produce the enzyme keratinase (Mangiaterra et al. 2001).

Fusarium solani (FS5) was obtained from cassava tuber endophytic fungi isolation from Lembang area. This fungus is commonly found in cassava tubers and can cause tuber rot (Boas et al. 2017). Cassava tubers that grow in different areas show different types of inhabited fungi strains. This can be due to the seasonal variations and environmental factors, both biotic and abiotic factors (Irawati et al. 2014). Further research is needed to determine the positive and negative impacts of the Fusarium spp.

\section{Lasiodiplodia sp.}

One isolate of Lasiodiplodia sp. FS12 was isolated successfully from cassava collected from Makasar (Figure 3). Lasiodiplodia sp., phylogenetic tree construction of Diplodia mutitla CBS 136015 and Bottryosphaeria obtusa CBS 11255 were used as out-groups. The results showed that the FS12 strain forms a clade that was similar to $L$. egyptiaceae BOT10, L. aeuphorbicola CMM 3609, L. hormozganensis IRANI500C, L. parva CBS 45678T, CBS494.78, and Botryosphaeria rhodina CBS16496T, with the value of the bootstrap was $48 \%$ (Figure 3.A). The genus of Lasiodiplodia was also found in Brazil which inhabited cassava (Boas et al. 2017). This endophytic fungus is found in other plants, such as Albizia chinensis (Rakhmawati and Prihatini 2016).

Morphologically, the colonies of FS12 grew covering up the surface of the PDA media, $6 \mathrm{~cm}$ diameter size of Petri dishes on the third day of incubation. The FS12 strain has grayish-white mycelium which can turn to blackish with thick and smooth shape like cotton characteristics (Figure 3.B). This strain can turn the color of PDA media into black. Microscopically, these colonies have insulated hyphae and no reproductive organs (Figure 3.C).

This fungus often causes diseases such as rotting fruit and damage on the stems. It is also known as endophytic fungi (Slippers and Wingfield 2007). Lasio diplodia usually grows in areas with tropical and subtropical climates. This fungus often causes diseases in plants (Abdollahzadeh et al. 2010). Boas et al. (2017) reported that Lasiodiplodia spp. can cause black rot in cassava. A previous study showed that the presence of fungus Lasiodiplodia spp., on the gatotan (fermentation from cassava tubers that is stored for a few days before being steamed) and does not have any bad effect on human health (Purwandari et al. 2014). Of course, this matter needs further research.

Lasiodiplodia is an anamorph form of Botryosphaeria. In this study, strain FS12 formed a clade equal to $L$. egyptiaceae BOT10, L. euphorbicola CMM3609, L. hormozganensis IRAN 1500C, L. parva CBS456.78 and CBS 494.78, and Botryosphaeria rhodina CBS16496. The use of other genes, such as elongation factor $\alpha$ and $\beta$ tubulin, is required to separate FS12 strain in separate clades (Jang et al. 2012).

\section{Nectria pseudotrichia}

The FS11 strain was identified as Nectria pseudotrichia. Based on the molecular analysis, bootstrap value was $81 \%$ (Figure 4). The FS11 strain formed a monophyletic clade with $N$. pseudotrichia CBS551.84 (Figure 4.A). Cosmospora coccinea AR2741 was used as an out-group. This fungus was isolated from cassava tubers collected from Subang. The FS11 strain grew covering up the PDA media, up to $6 \mathrm{~cm}$ in diameter after five days of incubation, has a smooth colony surface, and white color (Figure 4.B). Microscopically, these fungi have septate hyphae (Figure 4.C). However, reproductive organ was not found in this isolate. Endophytic fungi in the genus Nectria were also found in the other plants, such as Annona squamosa (Yunianto et al. 2012). However, $N$. pseudotrichia fungi was not found as endophyte in the other plant species. This fungus lives in tropical and subtropical areas. N. pseudotrichia looks like saprophytic. However, some species are endophytes. This species functions as a plant pathogen in the tropics region (Hirooka et al. 2012). 


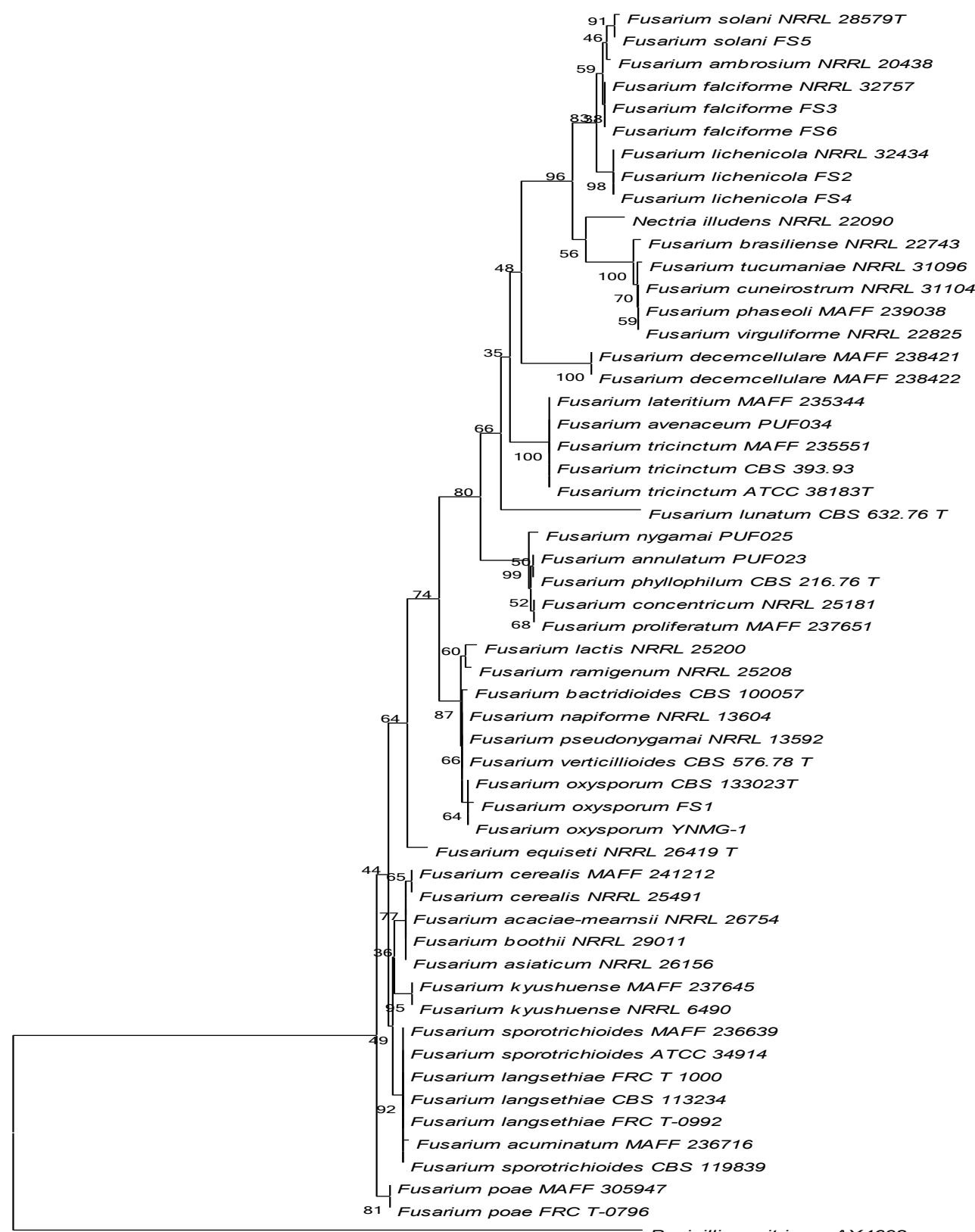

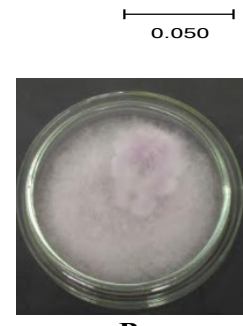

B

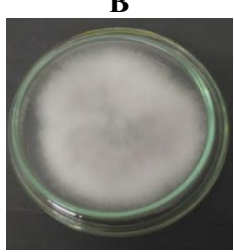

F

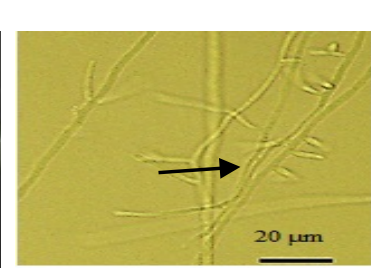

C

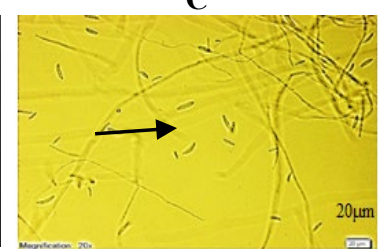

G

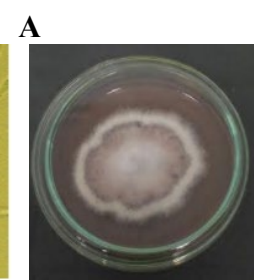

D

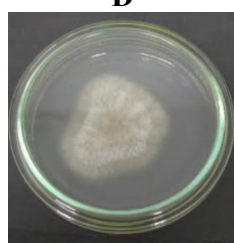

H

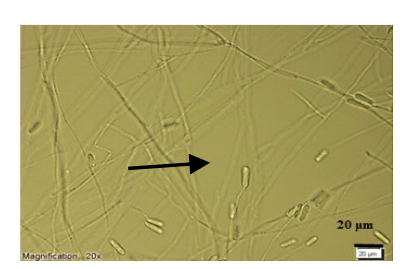

$\mathbf{E}$

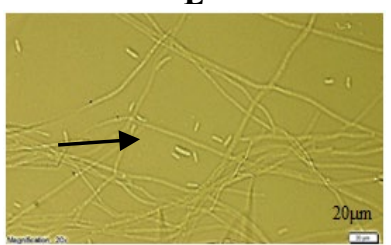

I

Figure 2. Phylogenetic tree of Fusarium spp. based on NJ analysis with 1000 bootstrap replicates. A. Penicillium citrinum AX4602 was used as an out-group. Morphological identification of: B. Colony of Fusarium oxysporum FS1; C. Microconidia of Fusarium oxysporum FS1; D. Colony of Fusarium lichenicola FS2; E. Microconidia of Fusarium lichenicola FS2; F. Colony of Fusarium falciforme FS3; G. Microconidia of Fusarium falciforme FS3; H. Colony of Fusarium solani FS5; and I. Microconidia of Fusarium solani FS5. 


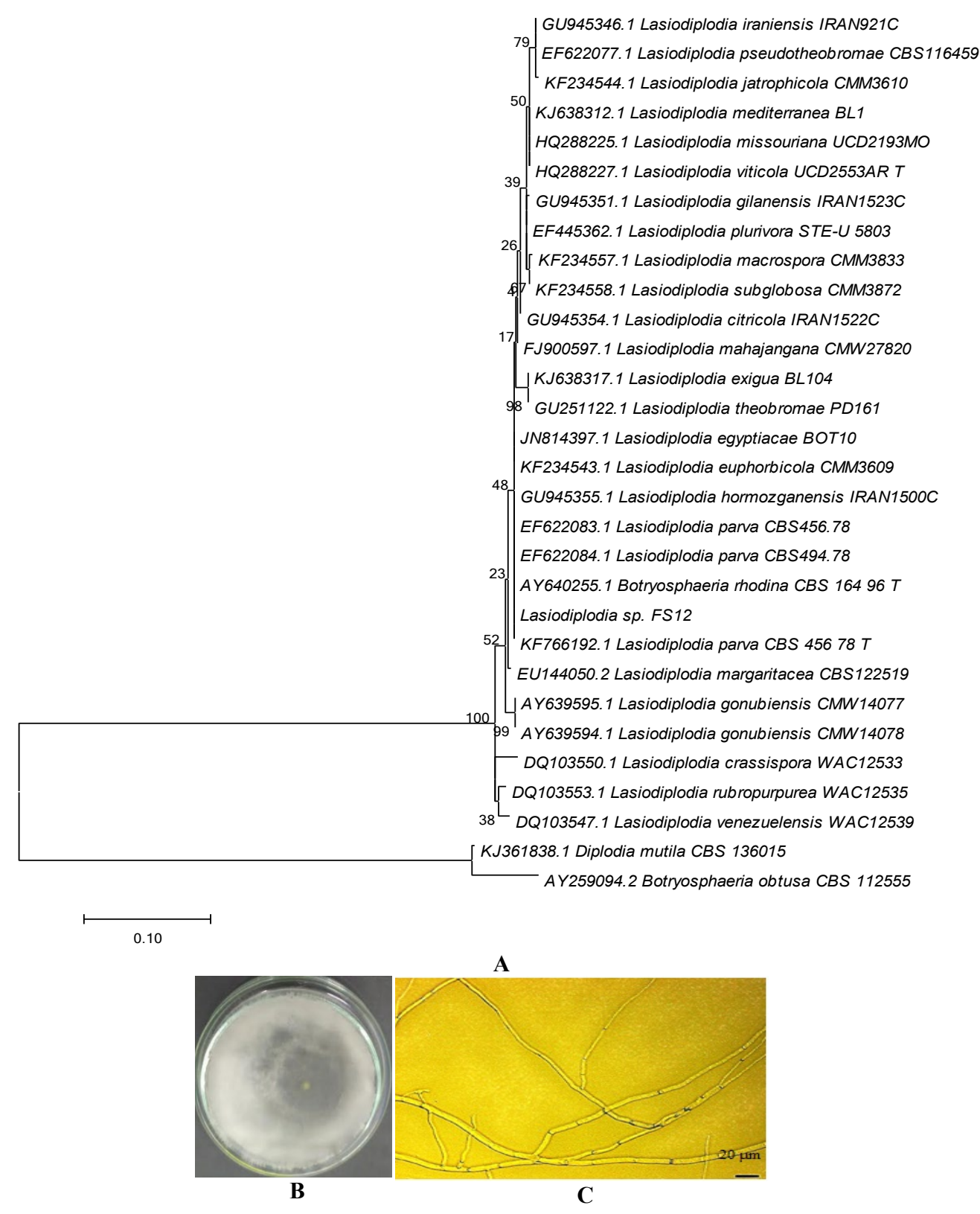

Figure 3. Phylogenetic tree of: A. Lasiodiplodia sp. based on ML analysis with 1000 bootstrap replicates, Diplodia mutila CBS136015 and Botryosphaeria obtuse DBS112555 was used as the out-group. Morphological identification of endophytic fungi: B. colony of Lasiodiplodia sp. FS12; C. septate hyphae of Lasiodiplodia sp. FS12.

\section{Penicillium citrinum}

The FS13 strain was isolated successfully from cassava collected from Subang area. The molecular identification results showed that the FS13 strain formed a clade that was the same as Penicillium citrinum NRRL1841T, NRRL35449, NRRL35448, NRRL35434, P-1637 with a high bootstrap value of $100 \%$ (Figure 5). Thus, it can be ascertained that this strain was $P$. citrinum. Paecilomyces variotii DTO63F5 used as outgroup (Figure 5.A). Besides as a part of an endophyte collected from cassava, $P$. citrinum has also been found on other plants such as rice grains (Reddy et al. 2010) and quina (Hidayat et al. 2016a). Another study also reported Penicillium capsulatum found in Centella asiatica (Radiastuti et al. 2019).

Based on macroscopic morphological observations, it was found that colonies started with white and turned bluish-green color after 5 days of incubation. The colony was hard-skinned and the surface looks like powder (Figure 5.B). Microscopically, this fungus has a metula and fialid shaped like a bottle and branched conidiophores. The conidia were round and arranged in a basipetal fashion (Figure 5.C). 


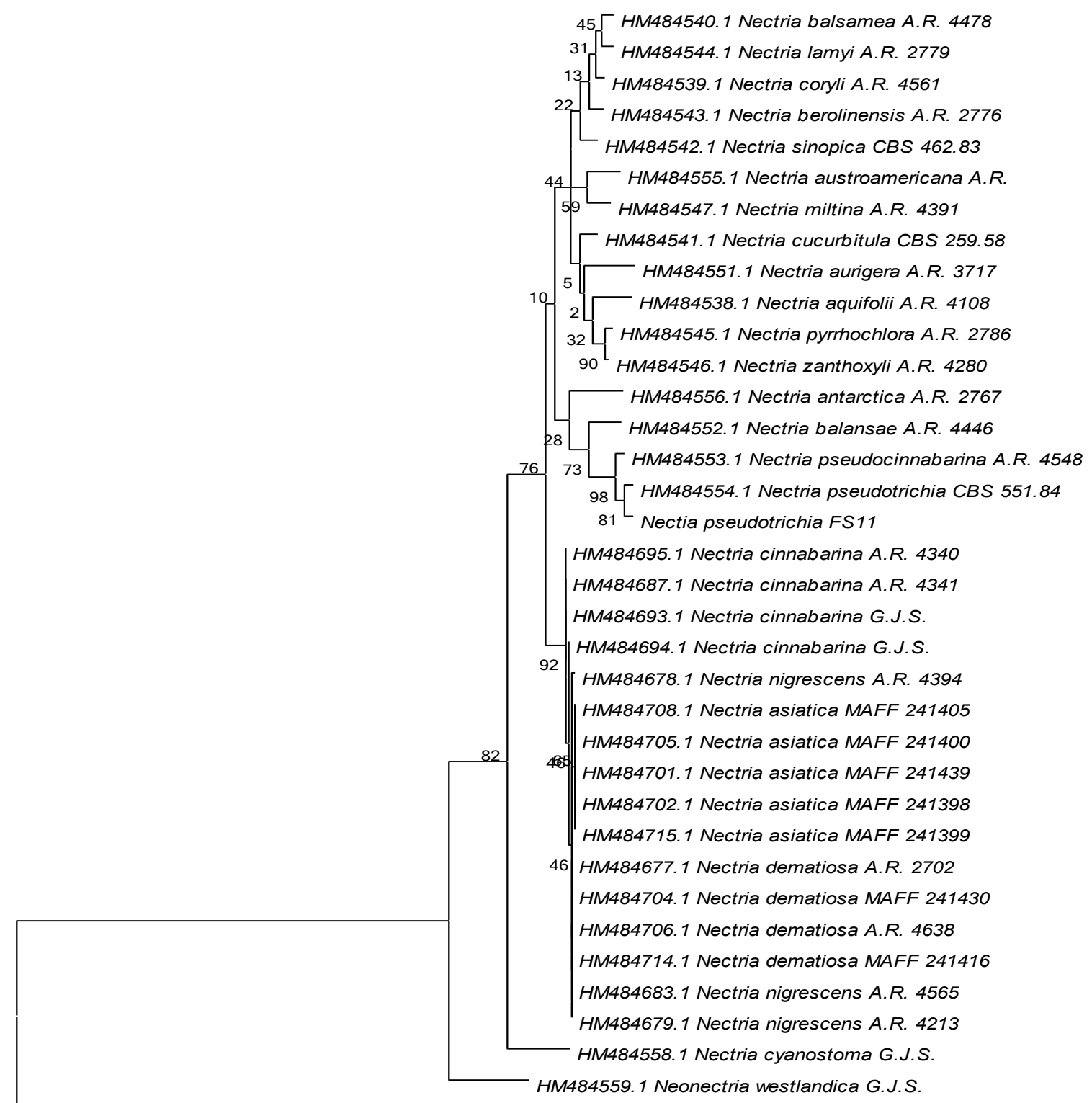

HM484537. 1 Cosmospora coccinea A.R. 2741

0.10

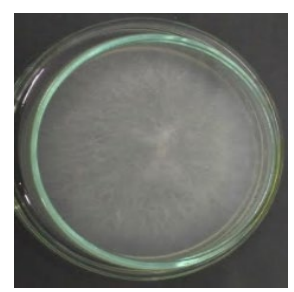

B
A

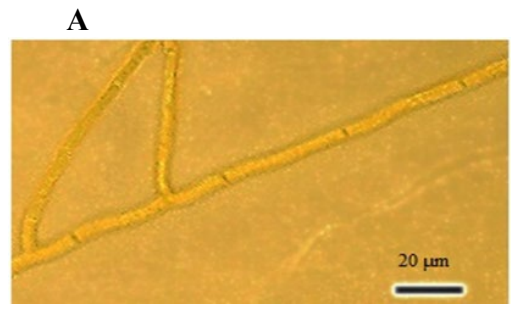

C

Figure 4. Phylogenetic tree of: A. Nectria pseudotrichia based on ML analysis with 1000 bootstrap replications. Cosmospora coccinea AR2741 was used as an out-group. Morphological identification of endophytic fungi: B. Colony of Nectria pseudotrichia FS11 in the PDA media; C. Septate hyphae of Nectria pseudotrichia FS11. 


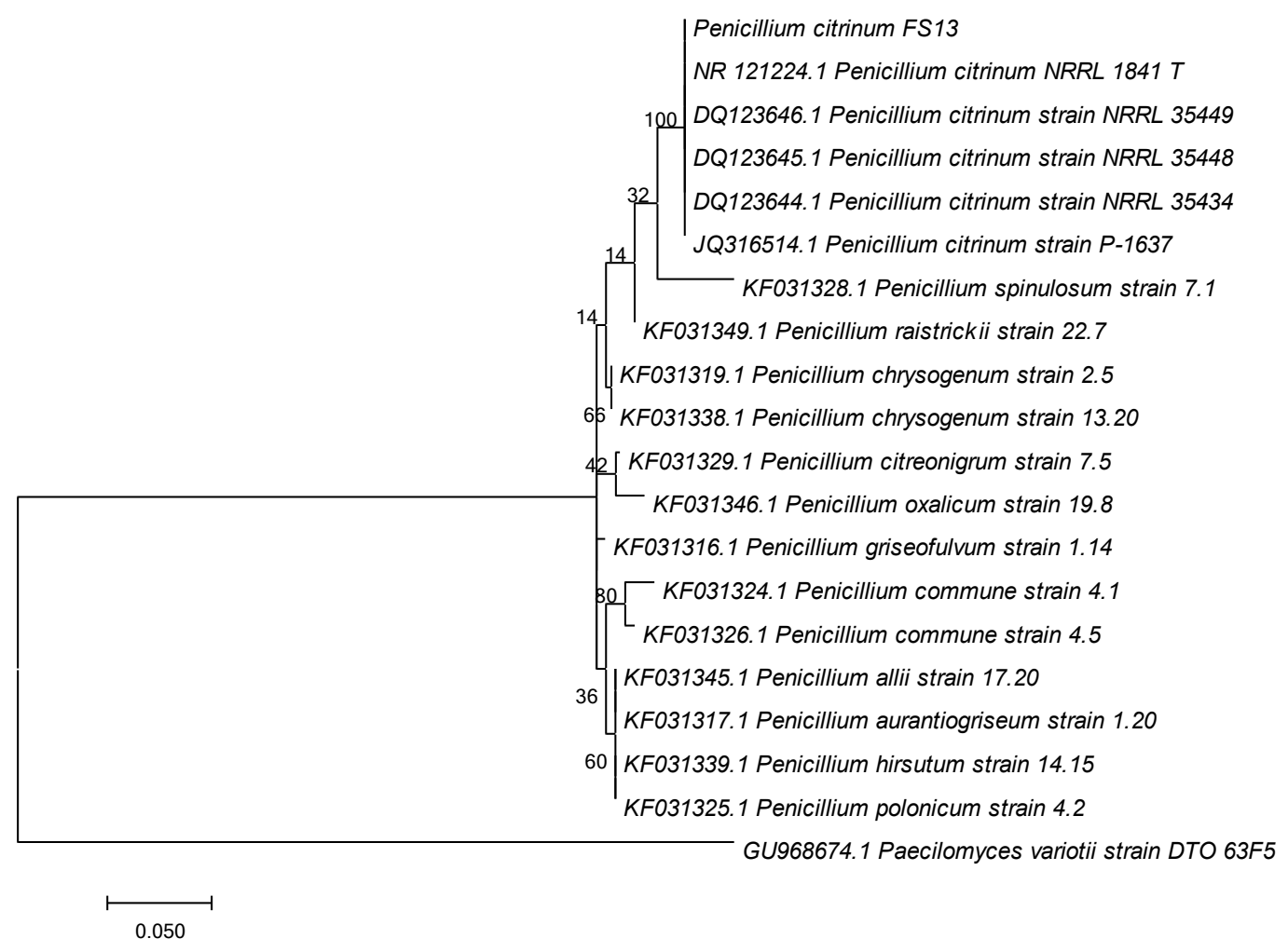

A

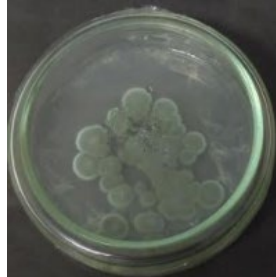

B

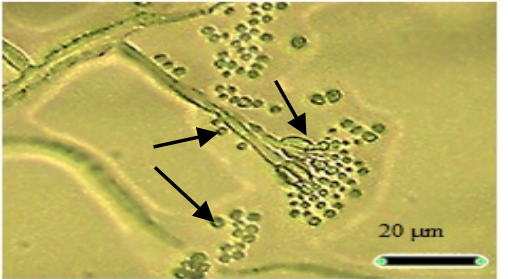

C

Figure 5. Phylogenetic tree of: A. Penicillium citrinum based on ML analysis with 1000 times bootstrap replications. Paecilomyces variotii DTO63F5 was used as the out-group. Morphological identification of endopytic fungi: B. Colony of Penicillium citrinum FS13; C. Microscopic profiles of Penicillium citrinum FS13.

Penicillium citrinum is a fungus that usually grows in plantations or forests of tropical areas (Amaria et al. 2013). The characteristics of the $P$. citrinum are bluish-green colonies, powdery surfaces, aseptate hyphae, insulated conidiophores, branched, and it has smooth walls. Penicillium can act as a biopesticide and biofertilizer because it produces mycotoxin compounds such as citrinin to inhibit the growth of pathogens. In addition, Penicillium is used as a decomposer due to its ability to produces cellulose and endoglucanases, which can degrade dead plants to fertilize the soil (Amaria et al. 2013). Citrinin is a compound that is toxic and harmful if it is consumed by humans or animals and can cause chronic diseases. These compounds can contaminate soil, water, plants, and agricultural products (Khosravi et al. 2012).

\section{Schizophyllum commune}

The FS11 strain was molecularly identified as Schizophyllum commune with a bootstrap value of $76 \%$ (Figure 6). This strain was anamorph form collected from cassava in Bogor, which formed monophyletic together with KF679517 S. commune and S. commune MUCL 29305 , formed a sister clade with several $S$. radiatum. Mortierella elongata MAFF425591 was used as the outgroup (Figure 6.A). Based on macroscopic morphological observations, this fungus covered the PDA media with a 6 $\mathrm{cm}$ diameter on the fifth day of incubation. The colonies formed fluffy mycelium, which was white and thin (Figure 6.B). Microscopically, S. commune has aseptate hyphae, and formed no reproductive structure (Figure 6.C). 


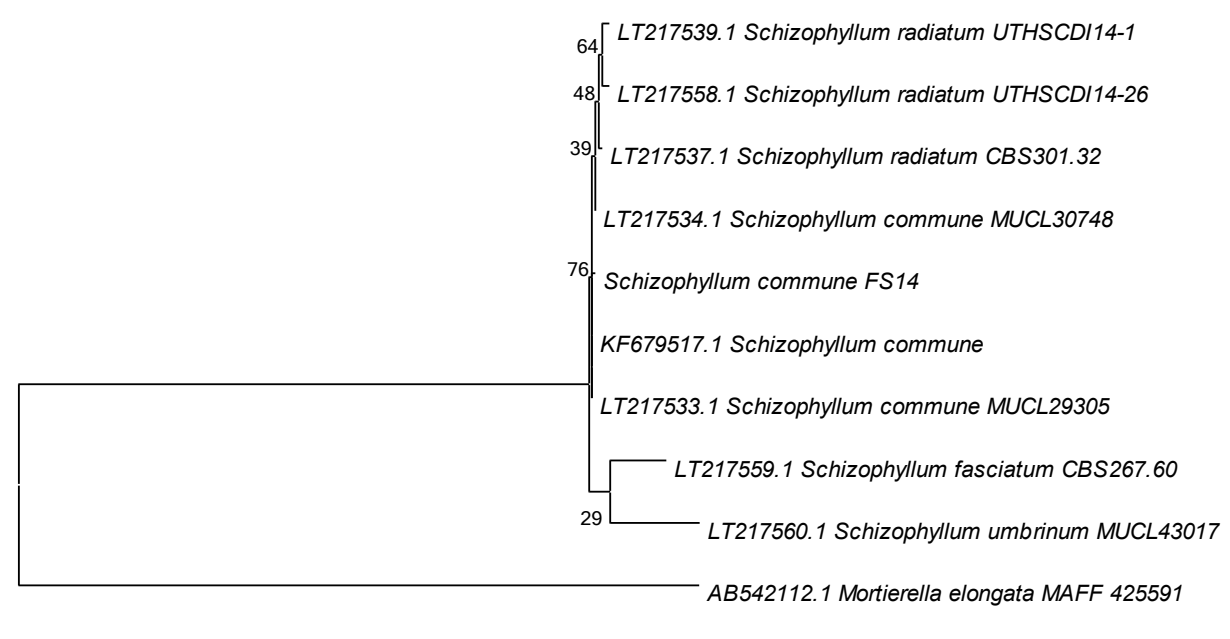

0.10

$\mathbf{A}$

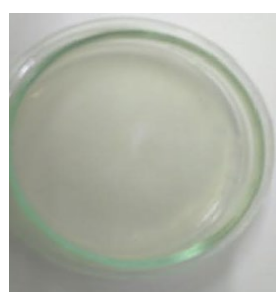

B

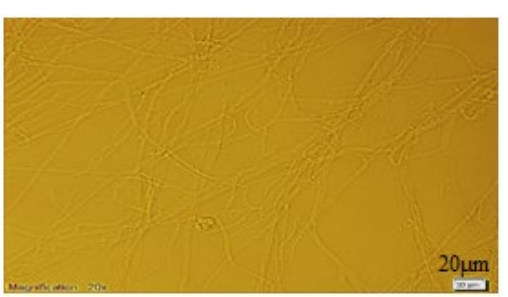

$\mathbf{C}$

Figure 6. A. Phylogenetic tree of Schizophyllum commune based on ML analysis with 1000 bootstrap replicates, Mortierella elongate MAFF425591 was used as out-group. Morphological identification of endophytic fungi: B. Colony of Schizophyllum commune FS14; C. Septate hyphae of Schizophyllum commune FS14.

S. commune can also be found as an endophyte in other host plants, such as Panax ginseng (Zhai et al. 2017) and Piper hispidum (Orlandelli et al. 2012). This fungus has previously been found in Gabon ebony fruit and belongs to an endophytic fungus that can grow in tropical environments (Douanla-MeliLanger 2012). S. commune is also a saprophytic fungus that belongs to the Basidiomycota, and it is often found in woody plants in the form of teleomorphs, especially in the pith of plants. $S$. commune can break down cellulose and hemicellulose, but cannot break down lignin, due to cellulose enzymes dominate its extracellular activity. These fungal spores are classified as pathogens when inhaled by humans which can attack the human respiratory system and causing various diseases, such as sinusitis, allergies, and respiratory tract infections. In the form of teleomorph, this fungus is edible and has a compound namely Schizophyllan, acts as an antitumor, anti-cancer, and can increase endurance. This compound is a homopolysaccharide and water-soluble (Salahuddin 2008).

In conclusion, a total of fourteen endophytic fungal strains in cassava tubers have been isolated from 8 areas, and identified as six Fusarium strains, namely Fusarium solani (1 strain), F. lichenicola (2 strains), $F$, oxysporum (1 strain), and $F$. falciforme (2 strains). Four Aspergillus strains, namely Aspergillus sp. (3 strains) and A fumigatus
(1 strain). Followed by four other species such as Lasiodiplodia sp, Nectria pseudotrichia, Penicillium citrinum, and Schizophyllum commune. Molecular identification is needed to confirm its proper morphology. The use of other genes, such as elongation factor $\alpha$ and $\beta$ tubulin, is required to separate strains into separate clades. Further research is needed to determine the positive and negative impacts of the fungus found in cassava tubers.

\section{ACKNOWLEDGEMENTS}

This research was supported by Atma Jaya Catholic University of Indonesia under Faculty Grant Scheme.

\section{REFERENCES}

Abdollahzadeh J, Javadi A, Goltapeh EM, Zare R, Phillips A. 2010. Phylogeny and morphology of four new species of Lasiodiplodia from Iran. Persoonia: Mol Phylogeny Evol Fungi 25: 1-10.

Akmalasari I, Purwati ES, Dewi RS. 2013. Isolasi dan identifikasi jamur endofit tanaman manggis (Garcinia mangostana L.). BIOSFERA: A Sci J 30: 82-89.

Amaria W, Taufiq E, Harni R. 2013. Seleksi dan identifikasi jamur antagonis sebagai agens hayati jamur akar putih Rigidoporus microporus pada tanaman karet. J Ind Beverage Crops 4: 55-64. [Indonesian] 
Barnett HL, Hunter BB. 1998. Illustrated genera of imperfect fungi. American Phytopathological Society. APS Press, West Virginia

Boas SAV, Oliveira SASd, Bragança CAD, Ramos JB, Oliveira EJd. 2017. Survey of fungi associated with cassava root rot from different producing regions in Brazil. Sci Agricola 74: 60-67.

Chadha N, Mishra M, Prasad R, Varma A. 2014. Root endophytic fungi: research update. J Biol Life Sci 5: 135-158.

Dagenais TR, Keller NP. 2009. Pathogenesis of Aspergillus fumigatus in invasive aspergillosis. Clin Microbiol Rev 22: 447-465.

Douanla-Meli C, Langer E. 2012. Diversity and molecular phylogeny of fungal endophytes associated with Diospyros crassiflora. Mycology 3: $175-187$.

Fuchs J-G, Moënne-Loccoz Y, Défago G. 1997. Nonpathogenic Fusarium oxysporum strain Fo47 induces resistance to Fusarium wilt in tomato. Plant Dis 81: 492-496.

Hidayat I, Radiastuti N, Rahayu G, Achmadi S, Okane I. 2016a. Endophytic fungal diversity from Cinchona calisaya based on phylogenetic analysis of the ITS ribosomal DNA sequence data. Curr Res Environ Appl Mycol 6: 132-142.

Hidayat I, Radiastuti N, Rahayu G, Achmadi S, Okane I. 2016b. Three Quinine and Cinchonidine producing Fusarium species from Indonesia. Curr Res Environ Appl Mycol 6: 20-34.

Hirooka Y, Rossman AY, Samuels GJ, Lechat C, Chaverri P. 2012. A monograph of Allantonectria, Nectria, and Pleonectria (Nectriaceae, Hypocreales, Ascomycota) and their pycnidial, sporodochial, and synnematous anamorphs. Stud Mycol 71: 1-210.

Ilyas M. 2006. Isolation and identification of mould inhabiting plant rizosphere in Gunung Mutis Natural Reserve, East Nusa Tenggara. Biodiversitas 7: 216-220.

Innis MA, Gelfand DH, Sninsky JJ, White TJ. 2012. PCR protocols: a guide to methods and applications. Academic Press, Amsterdam.

Irawati AF, Hartati S, Windriyati RD. 2014. Pemanfaatan cendawan endofit dalam mengingkatkan kualitas bibit tanaman padi. Buletin Pertanian Perkotaan 4: 30-40. [Indonesian]

Jang J-H, Lee JH, Ki C-S, Lee NY. 2012. Identification of clinical mold isolates by sequence analysis of the internal transcribed spacer region, ribosomal large-subunit D1/D2, and $\beta$-tubulin. Ann Lab Med 32: 126132.

Khosravi AR, Sheikhkarami M, Shokri H, Sabokbar A. 2012. Genetic Variability of citrinin-producing Penicillium citrinum strains as occupational health hazards in Northern Iran/Genska Varijabilnost Citrinin. Arhiv Za Higijenu Rada I Toksikologiju 63: 489-496.

Lacap D, Hyde K, Liew E. 2003. An evaluation of the fungal 'morphotype' concept based on ribosomal DNA sequences. Fungal Divers 12: 53 66.

Mangiaterra M, Giusiano G, Smilasky G, Zamar L, Amado G, Vicentán C. 2001. Keratomycosis caused by Cylindrocarpon lichenicola. Sabouraudia 39: 143-145

Mostert L, Crous PW, Kang J-C, Phillips AJ. 2001. Species of Phomopsis and a Libertella sp. occurring on grapevines with specific reference to South Africa: morphological, cultural, molecular and pathological characterization. Mycologia 93: 146-167.

Nurzannah SE, Lisnawita L, Bakti D. 2014. Potensi jamur endofit asa cabai sebagai agens hayati untuk mengendalikan layu fusarium (Fusarium oxysporum) pada cabai dan interaksinya. Jurnal Agroekoteknologi Universitas Sumatera Utara 2: 100407. [Indonesian]

Onana B, Essono G, Nyegue M, Tchikoua R, Ambang Z, Ayodele M. 2015. Natural occurrence of Fusarium species and fumonisins in stored cassava chips. Afr J Microbiol Res 9: 2257-2269.

Oramahi H, Sumardiyono C, Pusposendjojo N, Haryadi H. 2006. Identifikasi jamur genus Aspergillus pada gaplek di kabupaten gunung kidul. Jurnal Perlindungan Tanaman Indonesia 12: 25-32. [Indonesian]

Orlandelli R, Alberto R, Rubin Filho C, Pamphile J. 2012. Diversity of endophytic fungal community associated with Piper hispidum (Piperaceae) leaves. Genet Mol Res 11: 1575-1585.

Purwandari U, Tristiana G, Hidayati D. 2014. Gluten-free noodle made from gathotan flour: antioxidant activity and effect of consumption on blood glucose level. Int Food Res J 21: 1951-1956.

Radiastuti N, Susilowati DN, Bahalwan HA. 2019. Phylogenetic study of endophytic fungi associated with Centella asiatica from Bengkulu and Malaysian accessions based on the ITS rDNA sequence. Biodiversitas 20.

Rakhmawati A, Prihatini I. 2016. Isolasi dan identifikasi kapang endofit dari pohon sengon provenan Kepulauan Solomon berdasarkan morfologi dan molekuler rDNA ITS. Biologi-S1 5: 15-27. [Indonesian]

Reddy K, Nurdijati S, Salleh B. 2010. Efficacy of aqueous medicinal plant extracts on growth and citrinin production by Penicillium citrinum isolated from rice grains. Afr J Microbiol Res 4: 2562-2565.

Riddell RW. 1950. Permanent stained mycological preparations obtained by slide culture. Mycologia 42: 265-270.

Rubini MR, Silva-Ribeiro RT, Pomella AW, Maki CS, Araújo WL, Dos Santos DR, Azevedo JL. 2005. Diversity of endophytic fungal community of cacao (Theobroma cacao L.) and biological control of Crinipellis perniciosa, causal agent of Witches' Broom Disease. Int $\mathrm{J}$ Biol Sci 1: 24-33.

Salahuddin MAH. 2008. Biological activities of Schizophyllum commune Fr. [Dissertation]. University Malaya, Kuala Lumpur. [Malaysia]

Slippers B, Wingfield MJ. 2007. Botryosphaeriaceae as endophytes and latent pathogens of woody plants: diversity, ecology and impact. Fungal Biol Rev 21: 90-106.

Song J, Pongnak W, Soytong K. 2016. Antifungal activity of endophytic fungi from palm trees against coffee anthracnose caused by Colletotrichum coffeanum. J Agric Sci Technol 12: 623-635.

Suciatmih S, Supriyati D. 2016. Isolasi, identifikasi, dan skrining jamur endofit penghasil agen biokontrol dari tanaman di lahan pertanian dan hutan penunjang Gunung Salak. Jurnal Teknologi Lingkungan 12: 171-186. [Indonesian]

Sucipto I, Munif A, Suryadi Y, Tondok E. 2015. Exploration of endophytic fungi from lowland rice as a biocontrol agent of blast disease in lowland rice. Jurnal Fitopatologi Indonesia 11: 211-218. [Indonesian]

Suriani S, Muis A. 2017. Fusarium pada tanaman jagung dan pengendaliannya dengan memanfaatkan mikroba endofit. Iptek Tanaman Pangan 11. [Indonesian]

Thongkamngam T, Jaenaksorn T. 2017. Fusarium oxysporum (F221-B) as biocontrol agent against plant pathogenic fungi in vitro and in hydroponics. Plant Prot Sci 53: 85-95.

Waweru B, Turoop L, Kahangi E, Coyne D, Dubois T. 2014. Nonpathogenic Fusarium oxysporum endophytes provide field control of nematodes, improving yield of banana (Musa sp.). Biol Control 74: 82-88.

Yunianto P, Rosmalawati S, Rachmawati I, Suwarso WP, Sumaryono W. 2012. Isolation and identification of endophytic fungi from srikaya plants (Annona squamosa) having potential secondary metabolites as anti-breast cancer activity. Microbiol Indones 6: 4-4.

Zhai X, Chen L, Jia M, Li C, Shen H, Ye B, Qin L, Han T. 2017. A stable beneficial symbiotic relationship between endophytic fungus Schizophyllum commune and host plant Panax ginseng. bioRxiv 175885. 